\title{
Flow-injection spectrophotometric determination of captopril in pharmaceutical formulations using a new solid-phase reactor containing AgSCN immobilized in a polyurethane resin
}

\author{
Fernando Campanhã Vicentini', Willian Toito Suarez², Éder Tadeu Gomes Cavalheiro³, \\ Orlando Fatibello-Filho ${ }^{1, *}$
}

\begin{abstract}
${ }^{1}$ Department of Chemistry, Federal University of São Carlos, UFSCar, ${ }^{2}$ Department of Chemistry, Federal University of Viçosa, UFV, ${ }^{3}$ Department of Chemistry and Molecular Physics, University of São Paulo, USP
\end{abstract}

\begin{abstract}
A simple flow-injection analysis procedure was developed for determining captopril in pharmaceutical formulations employing a novel solid-phase reactor containing silver thiocyanate immobilized in a castor oil derivative polyurethane resin. The method was based on silver mercaptide formation between the captopril and $\operatorname{Ag}(\mathrm{I})$ in the solid-phase reactor. During such a reaction, the $\mathrm{SCN}^{-}$anion was released and reacted with $\mathrm{Fe}^{3+}$, which generated the $\mathrm{FeSCN}^{2+}$ complex that was continuously monitored at $480 \mathrm{~nm}$. The analytical curve was linear in the captopril concentration range from $3.0 \times 10^{-4} \mathrm{~mol} \mathrm{~L}^{-1}$ to $1.1 \times 10^{-3} \mathrm{~mol} \mathrm{~L}^{-1}$ with a detection limit of $8.0 \times 10^{-5} \mathrm{~mol} \mathrm{~L}^{-1}$. Recoveries between $97.5 \%$ and $103 \%$ and a relative standard deviation of $2 \%$ for a solution containing $6.0 \times 10^{-4} \mathrm{~mol} \mathrm{~L}^{-1}$ captopril $(n=12)$ were obtained. The sample throughput was $40 \mathrm{~h}^{-1}$ and the results obtained for captopril in pharmaceutical formulations using this procedure and those obtained using a pharmacopoeia procedure were in agreement at a $95 \%$ confidence level.
\end{abstract}

Uniterms: AgSCN. Captopril/determination. Flow-injection. Polyurethane resin. Solid-phase reactor.

Um procedimento simples de análise por injeção em fluxo foi desenvolvido para a determinação de captopril em formulações farmacêuticas empregando um novo reator em fase sólida contendo tiocianato de prata imobilizado em resina poliuretana obtida a partir de óleo de mamona. O método foi baseado na formação de um mercapto composto de prata, no reator em fase sólida, obtido entre o captopril e $\mathrm{Ag}$ (I) imobilizada. Durante a reação, íons $\mathrm{SCN}^{-}$eram liberados e reagiam com $\mathrm{Fe}^{3+}$, gerando o complexo $\mathrm{FeSCN}^{2+}$, que foi continuamente monitorado em $480 \mathrm{~nm}$. A curva analítica foi linear no intervalo de concentração de captopril entre $3,0 \times 10^{-4}$ a $1,1 \times 10^{-3} \mathrm{~mol} \mathrm{~L}^{-1}$ com um limite de detecção de $8,0 \times 10^{-5} \mathrm{~mol} \mathrm{~L}^{-1}$. Recuperações entre $97,5-103 \%$ e desvio padrão relativo de $2 \%$ para uma solução contendo $6,0 \times 10^{-4} \mathrm{~mol} \mathrm{~L}^{-1}$ de captopril $(n=12)$ foram obtidos. A frequência de amostragem foi de $40 \mathrm{~h}^{-1} \mathrm{e}$ os resultados obtidos para captopril em formulações farmacêuticas utilizando este procedimento e o da Farmacopeia, estão de acordo em um nível de confiança de 95\%.

Unitermos: AgSCN. Captopril/determinação. Injeção em fluxo. Resina poliuretana. Reator em fase sólida.

\section{INTRODUCTION}

Captopril,1-[(2S)-3-mercapto-2-methyl propionyl]1-proline (Figure 1) is an angiotensin converting enzyme (ACE) inhibitor, which reduces peripheral resistance and

*Correspondence: O. Fatibello-Filho. Centro de Ciências Exatas e de Tecnologia, Departamento de Química, Universidade Federal de São Carlos. Rod. Washington Luis, km 235, Caixa Postal 676, 13.560-970 - São Carlos - SP, Brazil. E-mail: bello@ufscar.br lowers blood pressure (Rubin et al., 1978). This compound can also be used to treat congestive heart failure (Goodman, Gilman, 1996). Captopril contains a sulphydryl group and forms disulphides and endogeneous thiol-containing compounds (cysteine, glutathione), as well as disulphide dimmer of the parent compound (Vancea et al., 2009).

Since it is widely used in high blood pressure control all over the world, numerous analytical methods have been developed for the quantitative determination of this 


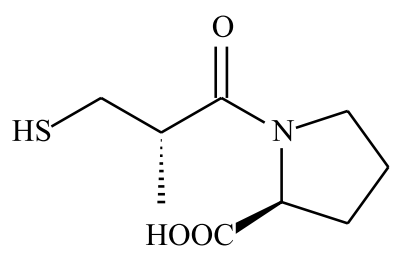

FIGURE 1 - Molecular structure of captopril.

analyte in pharmaceutical formulations. Methods based on titrimetric (Mohamed et al., 1983; Basavaiah, Prameela, 2004; Schmidt et al., 2009), spectrophotometric (Suarez et al., 2007; Suarez et al., 2009; Suarez et al., 2011), fluorimetric (Al-Ghannam et al., 2002; Chen, Cai, 2003), amperometric (Marcolino-Junior et al., 2009), conductometric (Lourenção et al., 2008), voltammetric (Ziyatdinova et al., 2006; Rezaei, Damiri, 2008; Karimi-Maleh et al., 2010), and chemiluminescence (Pulgarín et al., 2005) procedures have been previously described. The Brazilian Pharmacopeia recommends an iodimetric method for the determination of captopril in pharmaceutical formulations (Farmacopéia Brasileira, 1977).

The use of solid-phase reactors incorporated in flowinjection manifolds is a well-established methodology (Kojlo, Martínez-Calatayud, 1995). The reactor is generally constructed by incorporating oxidizing/reducing agents, insoluble salts, or ion exchange resins into a small column. The immobilization procedure is fairly expeditious, simple, and nonspecific (Pereira, Fatibello-Filho, 1998).

Solid-phase reactors are based on the immobilization of the reagents at a predefined point of the manifold. The sample zone is driven by the carrier stream through the reactor and conversion of the analyte takes place at the solid-solution interface (Tzanavaras, Themelis, 2007).

Some advantages of the use of solid-phase reactors in flow systems include lower consumption of reagents, greater stability, reproducible long-life supplies, and greater sensitivity and throughput.

Several procedures, utilizing solid-phase reactors that are based on the immobilization of insoluble salts such as $\mathrm{Zn}_{3}\left(\mathrm{PO}_{4}\right)_{2}$ (Suarez et al., 2007), $\mathrm{Ag}_{2} \mathrm{C}_{6} \mathrm{Cl}_{2} \mathrm{O}_{4}(\mathrm{Su}$ arez et al. 2009), $\mathrm{Fe}(\mathrm{OH})_{3}$ (Pereira, Fatibello-Filho, 1998), $\mathrm{CoCO}_{3}$ (Icardo et al., 1998; Corominas et al., 2005), AgCl (Marcolino-Junior et al., 2005), and $\mathrm{PbO}_{2}$ (Teixeira et al., 2002) in a polymeric matrix have been described in the literature. A typical immobilization procedure involves mixing the salt with polyester resin followed by the addition of a catalyst (methylethyl ketone).

Polyurethanes (PU) are versatile polymers that can be prepared as thermoplastic, thermosetting, elastomeric, foam, or adhesive by an appropriate choice of precursors. The remarkable properties of polyurethane include adhesion, abrasion electric resistance, hardness, chemical resistance to organic solvents, stability at low temperature, and tolerance to high humidity, as well as the ease of application, catalysis, and preparation of composite materials (Mendes et al., 2002). Another feature of the growing market demand is the use of polyols derived from vegetable oils (e.g. castor oil), a renewable source, and the simplicity of synthesis of derivatives, such as that used in the present study (Azevedo et al., 2009).

This study describes a new solid-phase reactor filled with an active phase consisting of silver thiocyanate dispersed in a castor oil polyurethane resin. The main advantages of such materials are their high resistance to organic solvents and the oily nature of the resin that provides a hydrophobic character to the final polymer, preventing a swelling effect from epoxy resins observed in other solid-phase reactors, when such materials are used in the aqueous media. Another interesting feature is that the polymer is composed from a bicomponent liquid system, the polyol (adhesive), and the prepolymer (hardener); the solid-phase is prepared by simply mixing the noncured precursors with the active reagent and the mixture is left to cure. The new reactor has been used in the determination of the antihypertensive captopril in pharmaceutical formulations, demonstrating its usefulness.

\section{EXPERIMENTAL}

\section{Apparatus}

The flow-injection system assembly is depicted in Figure 2. A peristaltic pump (Ismatec, model 7618-50, 8 -channel, Zurich, Switzerland) supplied with Tygon ${ }^{\circledR}$ pump tubing was used for the propulsion of the solutions.

Sample and reference solutions were inserted into the flow system by a three-piece homemade manual injector-commutator made from Perspex containing two fixed bars and a sliding central bar (Krug et al., 1986).

Flow-injection spectrophotometric measurements were carried out using a Genesis 20 (Thermospectronics, USA) spectrophotometer, model 435, equipped with a homemade glass flow-cell (optical path, $1.0 \mathrm{~cm}$ ).

The molecular absorption spectra were obtained in a linear diode array Multispec 1501 spectrophotometer (Shimadzu, Japan), using a quartz cuvette with an optical path of $1.00 \mathrm{~cm}$ and volume of $4 \mathrm{~mL}$.

\section{Reagents and solutions}

All solutions were prepared using water from an EasyPure RoDi purifying system (Barnstead, Thermo 


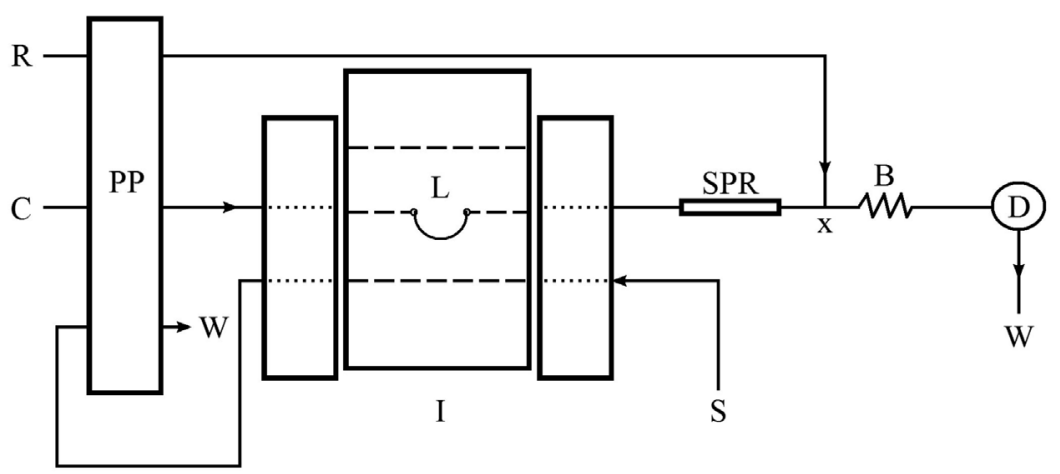

FIGURE 2 - Schematic diagram of the flow-injection system for spectrophotometric determination of captopril at $25^{\circ} \mathrm{C}$ : $\mathrm{C}, \mathrm{Milli}-\mathrm{Q}$ water carrier (1.1 mL min $\left.\mathrm{m}^{-1}\right)$; I, scheme of the sliding-bar manual commutator; PP, peristaltic pump; L, sample loop (500 $\left.\mu \mathrm{L}\right)$; S, sample or reference solutions; SPR, solid-phase reactor $(100 \mathrm{~mm} \times 2.0 \mathrm{~mm}$ i.d.) containing silver thiocyanate immobilized in a polyurethane resin; $\mathrm{R}, 1.0 \times 10^{-2} \mathrm{~mol} \mathrm{~L}^{-1} \mathrm{Fe}^{3+}$ in $1.0 \times 10^{-2} \mathrm{~mol} \mathrm{~L}^{-1} \mathrm{HNO}_{3}\left(1.1 \mathrm{~mL} \mathrm{~min}^{-1}\right)$; X, acrylic confluence; $\mathrm{B}$, reactor coil (50 $\mathrm{cm} \times 0.8 \mathrm{~mm}$ i.d.); D, spectrophotometer at $480 \mathrm{~nm}$; and $\mathrm{W}$, waste.

Scientific). All chemicals were analytical-reagent grade and were used without further purification.

The $5.0 \times 10^{-3} \mathrm{~mol} \mathrm{~L}^{-1}$ captopril stock solution was prepared by dissolving $108.6 \mathrm{mg}$ of this compound (Aldrich) in $1.0 \times 10^{-2} \mathrm{~mol} \mathrm{~L}^{-1} \mathrm{HNO}_{3}$ solution and completed in a $100.0 \mathrm{~mL}$ calibrated flask with the same acid solution. The reference solutions within the range of $3.0 \times 10^{-4} \mathrm{~mol} \mathrm{~L}^{-1}$ to $1.1 \times 10^{-3} \mathrm{~mol} \mathrm{~L}^{-1}$ were obtained by appropriate dilution of this stock solution with the same nitric acid solution in a $25.0 \mathrm{~mL}$ calibrated flask.

A $1.0 \times 10^{-2} \mathrm{~mol} \mathrm{~L}^{-1} \mathrm{Fe}\left(\mathrm{NO}_{3}\right)_{3} .9 \mathrm{H}_{2} \mathrm{O}$ (Aldrich) solution was prepared by dissolving $404 \mathrm{mg}$ in a $1.0 \times 10^{-2} \mathrm{~mol} \mathrm{~L}^{-1}$ nitric acid solution, and the volume was made up to $100 \mathrm{~mL}$ in a calibrated flask using the same acid solution in order to prevent hydrolysis of the Fe(III) ion.

\section{Preparation and analysis of the pharmaceutical samples}

For analysis, Brazilian commercial tablets of captopril, containing 12.5 and $25.0 \mathrm{mg}$, according to the label, were used. Thus, 10 tablets of each formulation of the drug were weighed and powdered in a mortar. The resulting powder was diluted in deionized water and filtrated. Suitable dilutions were made to obtain a final concentration of captopril within the linear range of the analytical and analyzed curve using the developed flow procedure. The obtained results were compared with the standard iodimetric procedure (Farmacopéia Brasileira, 1977).

\section{Preparation and immobilization of AgSCN}

For the preparation of the solid-phase reactor, $1.5 \mathrm{~g}$ $\mathrm{AgSCN}$ was mixed with $0.7 \mathrm{~g}$ of polyurethane resin and homogenized by manual mixing until an increase in the viscosity of the mixture was observed, and then kept at room temperature for $24 \mathrm{~h}$. After this, it was ground in a Willy-type mill (Marconi, MA 048).

The particle size was selected by passing the pulverized material through stainless steel sieves (Bertel, Brazil) with different mesh sizes (35, 48, 60 and 100 mesh). The solid-phase reactor was constructed by packing particles of 60-100 mesh, which were inserted with the aid of a syringe, in PTFE tubing $(100 \mathrm{~mm}$ long $\times 2.0 \mathrm{~mm}$ i.d). Pieces of glass wool were placed at both the ends of the tube to prevent fragment displacement through the transmission lines. The solid-phase reactor was inserted between the injector-commutator and the detector as shown in Figure 2.

\section{RESULTS AND DISCUSSION}

The principle of the determination of captopril employing a solid-phase reactor containing silver thiocyanate $(\mathrm{AgSCN})$ is based on the following precipitation (1) and complex (2) reactions:

$$
\begin{aligned}
& \mathrm{R}^{-\mathrm{SH}_{(\mathrm{aq})}}+\mathrm{AgSCN}_{(\mathrm{s})} \rightleftharpoons \mathrm{R}-\mathrm{SAg}_{(\mathrm{s})}+\mathrm{SCN}_{(\mathrm{aq})}^{-}+\mathrm{H}_{(\mathrm{aq})}^{+} \text {(Eq. 1) } \\
& \mathrm{Fe}_{(\mathrm{aq})}^{3+}+\mathrm{SCN}_{(\mathrm{aq})}^{-} \rightleftharpoons \mathrm{FeSCN}_{(\mathrm{aq})}^{2+}
\end{aligned}
$$

The reaction between silver thiocyanate and captopril leads to the displacement of thiocyanate and the formation of the well-known red complex with Fe(III) (Vogel, 1979; Baccan, 2001), which can be detected spectrophotometrically. When an aqueous captopril solution flowed through the solid-phase reactor packed with AgSCN entrapped in the polyurethane resin, $\mathrm{SCN}^{-}$ions were released from the reactor. The studies of chemical 
and hydrodynamic parameters were carried out using the flow-injection system depicted in Figure 2.

The univariated method was employed in all studies and was performed to identify a better balance between the magnitude and precision of analytical signals, the stability of baseline, and the sample throughput. The best conditions for the precipitation reaction between captopril and $\mathrm{Ag}$ (I) and the complex reaction between the anion thiocyanate displaced by the reactor and Fe (III) were studied.

Initially, the most appropriate carriers' solutions were tested, since the lifespan of the solid-phase reactor is directly related to the solution flowing through it. The acetate buffer was not studied once it forms a complex with $\mathrm{Fe}(\mathrm{III})$. In the same way, phosphate buffer was not used to prevent possible precipitation of $\mathrm{FePO}_{4(\mathrm{~s})}$. Sulfuric, hydrochloric, and phosphoric acids, as well as sodium and potassium hydroxides, were not tested since these acids and bases form insoluble salts with silver ions.

Thus, nitric acid solutions were studied as carriers. During this study, it was noted that the absorbance signals obtained using a $5.0 \times 10^{-3} \mathrm{~mol} \mathrm{~L}^{-1} \mathrm{HNO}_{3}$ solution were $20 \%$ lower than when using water. This decrease in the analytical signal is probably due to the difficulty in removing the acidic hydrogen from the captopril molecule (R-SH), because once in acidic medium, the displacement of the reaction toward the reactants occurs, as can be seen from the reaction represented in Eq. 1. Thus, water was employed in further experiments.

\section{Reaction conditions and flow-injection parameters}

The response of the flow-injection system was studied by varying the inner diameter and length of the reactor, the mass/mass ratios (AgSCN/polyurethane), and the particle sizes.

The internal diameter of the reactor was evaluated for $1.0,1.5,2.0$, and $3.0 \mathrm{~mm}$. The reactors with 1.0 and $1.5 \mathrm{~mm}$ were very difficult to pack. The reactor with 3.0 $\mathrm{mm}$ caused a pronounced dispersion of the sample zone. The reactor with $2.0 \mathrm{~mm}$ produced good sensitivity and adequate stability of the baseline and, consequently, was chosen for further experiments.

The influence of the solid-phase reactor length was evaluated from 3.0 to $12 \mathrm{~cm}$. According to Figure 3, the absorbance signals increased with increments in the reactor length, but an undesirable increase of the hydrodynamic pressure was observed for reactors longer than $10.0 \mathrm{~cm}$. So, a $10.0 \mathrm{~cm}$ reactor length was selected for further experiments.

The mass/mass ratios (AgSCN/polyurethane) of

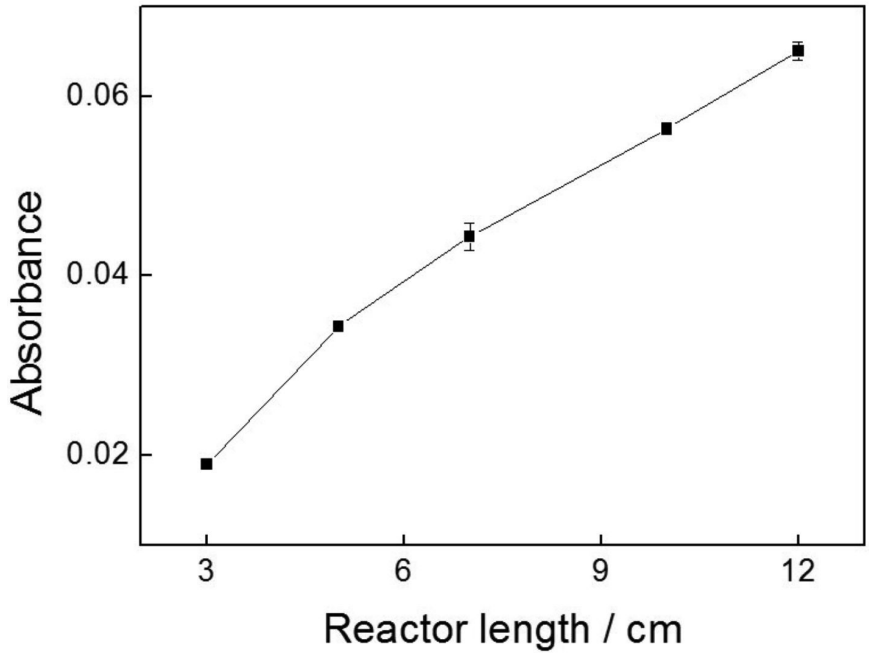

FIGURE 3 - Influence of reactor length $(\mathrm{cm})$ on the analytical signal.

$1: 2,1: 1$, and $2: 1(\mathrm{~m} / \mathrm{m})$ were evaluated. The sensitivity (slope of the analytical curve) increased with the mass of AgSCN incorporated in the polyurethane resin, as shown in Figure 4. Thus, a 2:1 ratio was selected, taking into account the magnitude of the analytical signal.

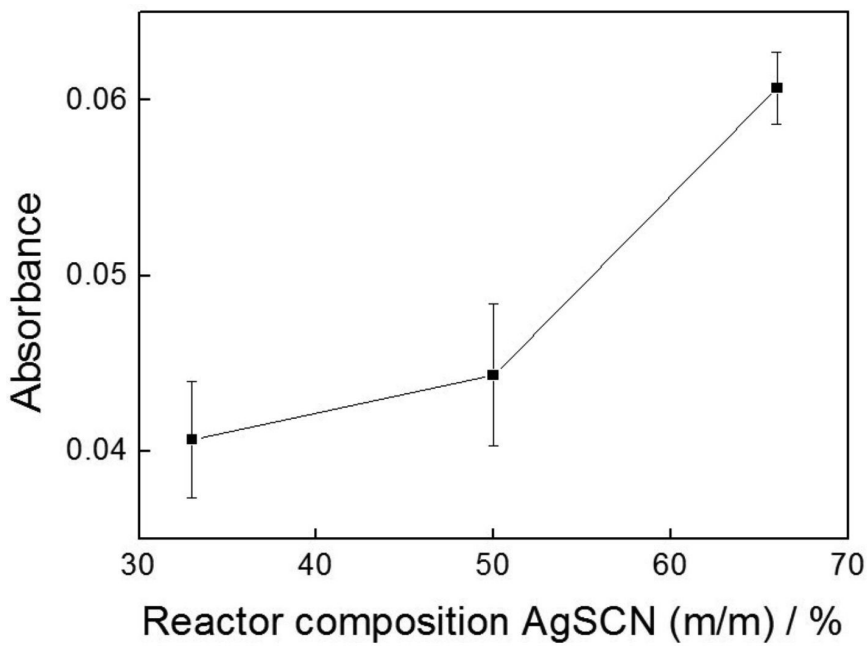

FIGURE 4 - Influence of reactor composition, $\operatorname{AgSCN}(\mathrm{m} / \mathrm{m})$, on the analytical signal.

The effect of particle size was studied in three size ranges (35-48, 48-60 and 60-100 mesh), selected by passing the particles through mesh sieves of known sizes. The 60-100 mesh particle size presented the highest absorbance signal and was selected for this reason.

\section{Flow-injection parameters}

The influence of Fe(III) concentration on the analyti- 
cal signal was evaluated in the range from $3.0 \times 10^{-3}$ to $5.0 \times 10^{-2} \mathrm{~mol} \mathrm{~L}^{-1}$ for a $1.0 \times 10^{-3} \mathrm{~mol} \mathrm{~L}^{-1}$ reference captopril solution. As can be seen in Figure 5, it was observed that the height of the peaks increased with the increase in $\mathrm{Fe}$ (III) concentration up to $1.0 \times 10^{-2} \mathrm{~mol} \mathrm{~L}^{-1}$ and remained practically constant for higher concentrations of this reagent. Therefore, a $1.0 \times 10^{-2} \mathrm{~mol} \mathrm{~L}^{-1} \mathrm{Fe}(\mathrm{III})$ solution was chosen for further experiments.

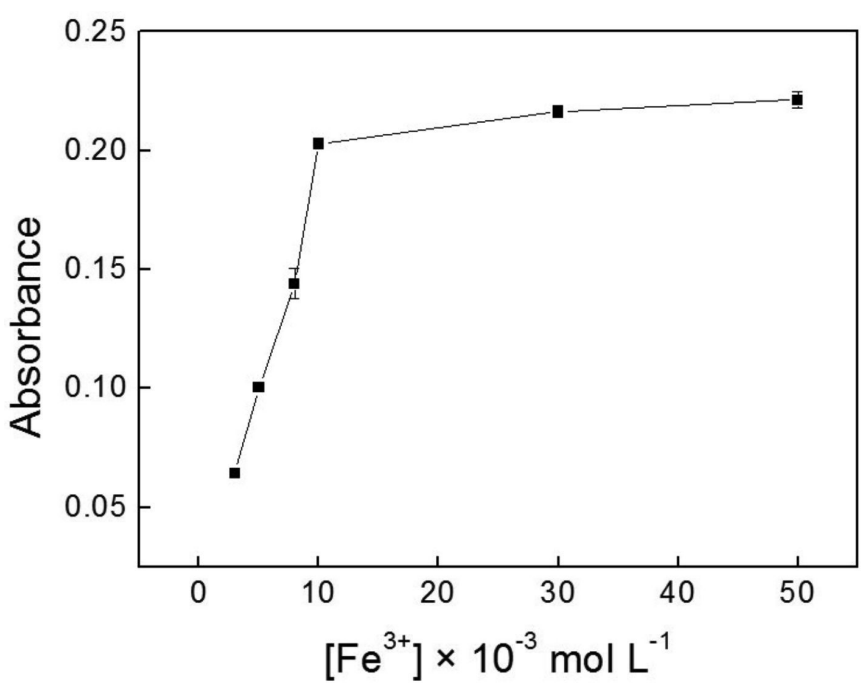

FIGURE 5 - Influence of Fe(III) concentration on the analytical signal.

Figure 6 shows the effect of the volumes of captopril inserted in the flow system by varying the volumes of the loop (L) between 100 and $700 \mu \mathrm{L}$, keeping the concentration of captopril at $1.0 \times 10^{-3} \mathrm{~mol} \mathrm{~L}^{-1}$. The analytical signal increased from 100 to $500 \mu \mathrm{L}$ for captopril, remaining almost constant at higher volumes. Consequently, the

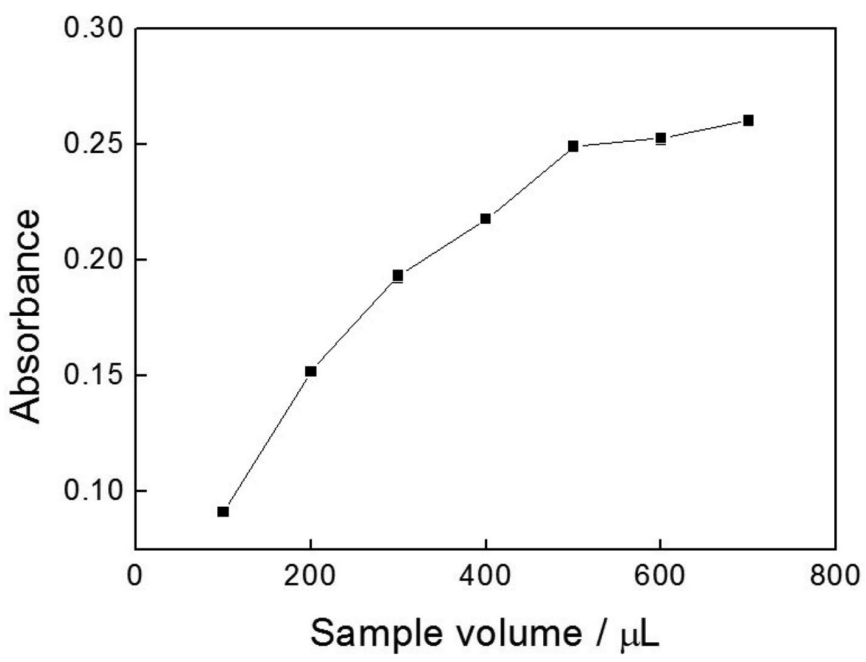

FIGURE 6 - Influence of sample volume on the analytical signal. volume of $500 \mu \mathrm{L}$ was chosen for the sample, based on the most effective balance of repeatability and magnitude of the analytical signal.

The influence of the reactor coil length (B) is shown in Figure 2, was also evaluated. The analytical signal was investigated in the $30-100 \mathrm{~cm}$ range. The analytical signal increased up to $50 \mathrm{~cm}$, while higher lengths led to a decrease in the analytical signal because of sample dispersion. Consequently, a length of $50 \mathrm{~cm}$ for reactor coil B was selected.

The effect of the total flow rate was investigated in the range of $0.6-4.4 \mathrm{~mL} \mathrm{~min}^{-1}$. Best results were obtained with a flow rate of $1.1 \mathrm{~mL} \mathrm{~min}^{-1}$. For higher flow rates, the sensitivity decreased due to the short contact time between the sample zone and the silver thiocyanate particles in the solid-phase reactor. A flow rate of $1.1 \mathrm{~mL} \mathrm{~min}{ }^{-1}$ was then selected taking into account the magnitude of the analytical signal, stability of the baseline, and low reagent consumption.

Table I presents the optimization of the chemical and flow-injection parameters studied in this work.

TABLE I - Study of chemical and flow-injection parameters

\begin{tabular}{lcc}
\hline Parameter & $\begin{array}{c}\text { Evaluated } \\
\text { range }\end{array}$ & $\begin{array}{c}\text { Selected } \\
\text { Value }\end{array}$ \\
\hline Reactor composition AgSCN $(\mathrm{m} / \mathrm{m})$ & $33 \%-66 \%$ & $66 \%$ \\
Particle size (Mesh) & $35-100$ & $60-100$ \\
Reactor length $(\mathrm{cm})$ & $3.0-12$ & 10 \\
Reactor diameter $(\mathrm{mm})$ & $1.0-3.0$ & 2.0 \\
Carrier flow rate $\left.(\mathrm{mL} \mathrm{min})^{-1}\right)$ & $0.6-4.4$ & 1.1 \\
$\mathrm{Fe}^{3+}$ flow rate $\left(\mathrm{mL} \mathrm{min}^{-1}\right)$ & $0.6-4.4$ & 1.1 \\
{$\left[\mathrm{Fe}^{3+}\right]\left(10^{-3}\right.$ mol L $\left.\mathrm{L}^{-1}\right)$} & $3.0-50$ & 10 \\
Sample volume $(\mu \mathrm{L})$ & $100-700$ & 500 \\
Reactor coil length $(\mathrm{cm})$ & $30-100$ & 50 \\
\hline
\end{tabular}

\section{Analytical characteristics}

Recoveries between $97.5 \%$ and $103 \%$ of captopril from five pharmaceutical formulations $(n=3)$ were obtained by using the flow-injection procedure. In this study, $2.0 \times 10^{-1}, 4.0 \times 10^{-1}$ and $6.0 \times 10^{-1} \mathrm{mmol} \mathrm{L}^{-1}$ of captopril were added to each product. The recovery results obtained suggest an absence of the matrix effect in the determination of captopril in those samples. Under optimum experimental conditions, the flow-injection system showed a linear response to captopril in the concentration range from $3.0 \times 10^{-4}$ to $1.1 \times 10^{-3} \mathrm{~mol} \mathrm{~L}^{-1}(\mathrm{~A}=0.0714+281.25 \mathrm{C}$; 
$\mathrm{r}=0.998$, where $\mathrm{A}$ is the absorbance and $\mathrm{C}$ the concentration of captopril in $\mathrm{mol} \mathrm{L}^{-1}$ ). The observed quantification limit (tenfold blank standard deviation/slope) was 1.0 $\times 10^{-4} \mathrm{~mol} \mathrm{~L}^{-1}$ and the detection limit (threefold blank standard deviation/slope) was $8.0 \times 10^{-5} \mathrm{~mol} \mathrm{~L}^{-1}$. Typical transient signals corresponding to a linear calibration graph for captopril are shown in Figure 7.

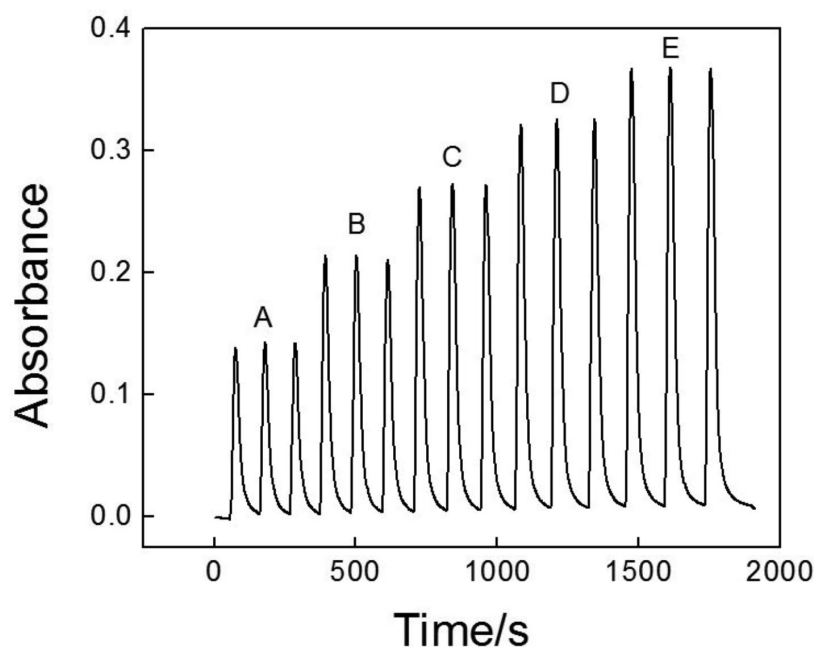

FIGURE 7 - Typical transient signals in triplicate for reference captopril solutions ((A) $3.0 \times 10^{-4}$; (B) $5.0 \times 10^{-4}$; (C) $7.0 \times 10^{-4}$; (D) $9.0 \times 10^{-4}$; and (E) $1.1 \times 10^{-3} \mathrm{~mol} \mathrm{~L}^{-1}$ ).

The precision of the flow system was evaluated in two concentration levels $\left(6.0 \times 10^{-4}\right.$ and $\left.1.0 \times 10^{-3} \mathrm{~mol} \mathrm{~L}^{-1}\right)$. The relative standard deviations (RSDs) obtained were lower than $2 \%(\mathrm{n}=12)$ for both solutions and a sample throughput of $40 \mathrm{~h}^{-1}$ was attained. The transient signals are shown in Figure 8.

To examine the efficiency of the solid-phase reactor containing immobilized $\mathrm{AgSCN}$ in the polyurethane resin, experiments were performed with consecutive injections

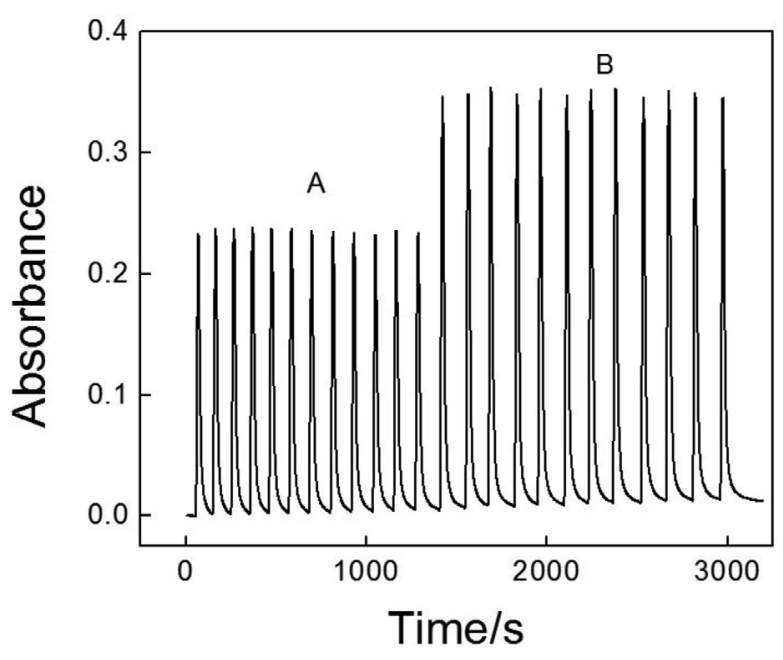

FIGURE 8 - Typical transient signals for reference solutions of captopril containing (A) $6.0 \times 10^{-4}$ and (B) $1.0 \times 10^{-3} \mathrm{~mol} \mathrm{~L}^{-1}$.

of captopril solutions. The reactors that were prepared presented high stability for at least eight hours under intense use in flowing solutions, when submitted to the consecutive injection of $3.0 \times 10^{-4}$ to $1.1 \times 10^{-3} \mathrm{~mol} \mathrm{~L}^{-1}$ captopril. After this period, a decrease in the order of $20 \%$ on the slope of the analytical curve was observed.

\section{Determination of captopril in pharmaceutical formulations}

The proposed flow-injection system was applied for the determination of captopril in pharmaceutical formulations. The results obtained by the proposed flow method and those obtained by the comparative method (Bittencount, 1977) are in agreement within a 95\% confidence level (t-paired test), confirming the accuracy of the proposed flow-injection system employing a solid-phase reactor containing AgSCN immobilized in the polyure-

TABLE II - Determination of captopril in pharmaceutical formulations using the comparative method and the proposed flowinjection method

\begin{tabular}{lccccc}
\hline \multirow{2}{*}{ Samples } & \multicolumn{3}{c}{ Captopril } & \multicolumn{2}{c}{ Relative Error/\% } \\
\cline { 2 - 6 } & Labeled & Comparative Method & Flow Method & $\operatorname{Er}_{1}$ & $\mathrm{Er}_{2}$ \\
\hline $\mathrm{A}$ & $12.5^{*}$ & $12.7 \pm 0.3$ & $12.8 \pm 0.1$ & 2.4 & 0.8 \\
$\mathrm{~B}$ & $25.0^{*}$ & $26.1 \pm 0.2$ & $25.8 \pm 0.1$ & 3.2 & -1.1 \\
$\mathrm{C}$ & $25.0^{*}$ & $25.3 \pm 0.2$ & $26.2 \pm 0.2$ & 4.8 & 3.5 \\
$\mathrm{D}$ & $12.5^{*}$ & $12.8 \pm 0.1$ & $13.0 \pm 0.4$ & 4.0 & 1.6 \\
$\mathrm{E}$ & $25.0^{*}$ & $26.3 \pm 0.3$ & $25.5 \pm 0.2$ & 2.0 & -3.0 \\
\hline
\end{tabular}

* mg/tablet

$\mathrm{n}=3$, mean \pm standard deviation, confidence level $95 \%$.

$\mathrm{Er}_{1}=$ relative error flow procedure $v s$. labeled value and $\mathrm{Er}_{2}=$ relative error flow procedure $v s$. comparative method. 
TABLE III - Comparison of analytical characteristics of flow procedures for captopril determination

\begin{tabular}{lcccc}
\hline Reference & $\begin{array}{c}\text { *LOD } \\
(\mu \mathrm{mol} \mathrm{L})\end{array}$ & $\begin{array}{c}\text { Linear range } \\
(\mu \mathrm{mol} \mathrm{L})\end{array}$ & $\begin{array}{c}\text { Sample throughput } \\
\left(\mathrm{h}^{-1}\right)\end{array}$ & $\begin{array}{c}\text { Coefficient of variation } \\
(\%)\end{array}$ \\
\hline Albero et al. $(1993)$ & 2.2 & $20-600$ & 90 & 0.6 \\
Tzanavaras et al. $(2002)$ & 12 & $<1200$ & 60 & 0.8 \\
Song et al. $(2006)$ & 0.01 & $0.032-4.6$ & 120 & 3.0 \\
Suarez et al. $(2007)$ & 5.0 & $10-800$ & 60 & 0.20 \\
Marcolino-Junior et al. $(2009)$ & 14 & $50-10000$ & 42 & 3.7 \\
Schmidt Jr. et al. $(2009)$ & 1.0 & $5-200$ & 72 & 1.2 \\
Suarez et al. $(2009)$ & 8.0 & $10-500$ & 70 & 0.35 \\
Schmidt Jr. et al. $(2011)$ & 3.0 & $10-400$ & 60 & 0.5 \\
Suarez et al. $(2011)$ & 30 & $50-400$ & 70 & 0.20 \\
Proposed system & 80 & $300-1100$ & 40 & 2.0 \\
\hline
\end{tabular}

*LOD $=$ Limit of Detection

thane resin. The results of the analysis are given in Table II.

Table III shows the analytical characteristics obtained in this study and in other analytical systems developed for the determination of captopril. The primary advantage of the proposed flow-injection system is the lower generation of waste.

\section{CONCLUSIONS}

This study demonstrates the possibility of analyzing captopril in pharmaceutical products using a flow-injection system with spectrophotometric detection and could be extended to determine other drugs since it generates a precipitate with silver ions. The proposed method is simple, quick, and could be carried out with good precision and accuracy. The new solid-phase reactor containing AgSCN immobilized in the developed polyurethane resin derived from vegetable oil is easy to make and has a long lifetime of 500 reproducible results. As the polyurethane resin used here is an inert material with mechanical resistance it proved to be an interesting material for the preparation of solid reactors containing modifiers.

\section{ACKNOWLEDGMENTS}

The authors gratefully acknowledge the financial support provided by Conselho Nacional de Desenvolvimento Científico e Tecnológico (CNPq), Coordenação de Aperfeiçoamento de Pessoal de Nível Superior (CAPES), and Fundação de Amparo à Pesquisa do Estado de São Paulo (FAPESP).

\section{REFERENCES}

ALBERO, M.I.; SÁNCHEZ-PETREÑO, C.; GARCIÁ, M.S.; RÓDENAS, V. Determination of captopril in pharmaceutical samples by flow injection analysis. $J$. Pharm. Biomed. Anal., v.11, n.10, p.887-891, 1993.

AL-GHANNAM, S.M.; EL-BRASHY, A.M.; AL-FARHAN, B.S. Fluorimetric determination of some thiol compounds in their dosage forms. Farmaco, v.57, n.8, p.625-629, 2002.

AZEVEDO, E.C.; CLARO-NETO, S.; CHIERICE, G.O.; LEPIENSKI, C.M. Aplicação de indentação instrumentada na caracterização mecânica de poliuretana derivada de óleo de mamona. Polímeros, v.19, n.4, p.336-343, 2009.

BACCAN, N.; ANDRADE, J.C.; GODINHO, O.E.S.; BARONE, J.S. Química analítica quantitativa elementar. São Paulo: Edgard Blusher, 2001. 308 p.

BASAVAIAH, K.; PRAMEELA, H.C. Assay of captopril by residual base neutralization methods. J. Sci. Ind. Res., v.63, n.10, p.817-819, 2004.

CHEN, Y.; CAI, R. Study and analytical application of inhibitory effect of captopril on multienzyme redox system. Talanta, v.61, n.6, p.855-861, 2003. 
COROMINAS, B.G.; PFERZSCHNER, J.; ICARDO, M.C.; ZAMORA, L.L.; MARTÍNEZ-CALATAYUD, J. In situ generation of $\mathrm{Co}$ (II) by use of a solid-phase reactor in an FIA assembly for the spectrophotometric determination of penicillamine. J. Pharm. Biomed. Anal., v.39, n.1-2, p.281-284, 2005.

FARMACOPÉIA BRASILEIRA. 3. ed. São Paulo: Organização Andrei, 1977. 1213 p.

GOODMAN, L.S.; GILMAN, A. The pharmacological basis of therapeutics. 9.ed. New York: McGraw-Hill, 1996. 1905 p.

ICARDO, M.C.; ZAMORA, L.L.; MARTÍNEZ-CALATAYUD, J. Solid-phase reactors as high stability reagent sources in flow analysis: selective flow injection spectrophotometric determination of cysteine in pharmaceutical formulations. Analyst, v.123, n.8, p.1685-1689, 1998.

KARIMI-MALEH, H.; ENSAFI, A.A.; ALLAFCHIAN, A.R. Fast and sensitive determination of captopril by voltammetric method using ferrocenedicarboxylic acid modified carbon paste electrode. J. Solid State Electrochem., v.14, n.1, p.9-15, 2010.

KOJLO, A.; MARTÍNEZ-CALATAYUD, J. Spectrofluorimetric flow injection determination of adrenaline with an iodine solid-phase reactor. Anal. Chim. Acta, v.308, n.1-3, p.334338, 1995.

KRUG, F.J.; BERGAMIN, F.H.; ZAGATTO, E.A.G. Commutation in flow injection analysis. Anal. Chim. Acta, v.179, p.103-118, 1986.

LOURENÇÃO, B.C.; MARCOLINO-JUNIOR, L.H.; FATIBELLO-FILHO, O. Determinação condutométrica de captopril em formulações farmacêuticas utilizando sulfato de cobre(II) como titulante. Quim. Nova, v.31, n.2, p.349$352,2008$.

MARCOLINO-JUNIOR, L.H.; BONIFÁCIO, V.G.; FATIBELLO-FILHO, O.; TEIXEIRA, M.F.S. Determinação turbidimétrica de dipirona em fluxo utilizando um reator contendo cloreto de prata imobilizado em resina poliéster. Quim. Nova, v.28, n.5, p.783-787, 2005.

MARCOLINO-JUNIOR, L.H.; BONIFÁCIO, V.G.; VICENTINI, F.C.; JANEGITZ, B.C.; FATIBELLOFILHO, O. Amperometric determination of captopril using a carbon paste electrode in flow analysis. Can. J. Anal. Sci. Spectrosc., v.54, n.1, p.45-51, 2009.
MENDES, R.K.; CLARO-NETO, S.; CAVALHEIRO, E.T.G. Evaluation of a new rigid carbon-castor oil polyurethane composite as an electrode material. Talanta, v.57, n.5, p.909-917, 2002.

MOHAMED, M.E.; ABOULENEIN, H.Y.; GADKARIEM, E.A. Potentiometric and visual titrimetric methods for analysis of captopril and its pharmaceutical forms. Anal. Lett., v.16, n.1, p.45-55, 1983.

PEREIRA, A.V.; FATIBELLO-FILHO, O. Flow injection spectrophotometric determination of $\mathrm{L}$-ascorbic acid in pharmaceutical formulations with on-line solid-phase reactor containing copper (II) phosphate. Anal. Chim. Acta, v.366, n.1-3, p.55-62, 1998.

PEREIRA, A.V.; FATIBELLO-FILHO, O. Spectrophotometric flow injection determination of L-ascorbic acid with a packed reactor containing ferric hydroxide. Talanta, v.47, n.1, p.11-18, 1998.

PULGARÍN, J.A.M.; BERMEJO, L.F.G.; LÓPEZ, P.F. Sensitive determination of captopril by time-resolved chemiluminescence using the stopped-flow analysis based on potassium permanganate oxidation. Anal. Chim. Acta, v.546, n.1, p.60-67, 2005.

REZAEI, B.; DAMIRI, S. Voltammetric behavior of multi-walled carbon nanotubes modified electrode-hexacyanoferrate(II) electrocatalyst system as a sensor for determination of captopril. Sens. Actuators B, v.134, n.1, p.324-331, 2008.

RUBIN, B.; ANTONACCIO, M.J.; HOROVITZ, Z.P. Captopril (SQ 14,225) (D-3-mercapto-2-methylpropanoyol-Lproline) - Novel orally active inhibitor of angiotensinconverting enzyme and antihypertensive agent. Prog. Cardiovasc. Dis., v.21, n.3, p.183-194, 1978.

SCHMIDT JR, E.; MELCHERT, W.R.; ROCHA, F.R.P. Flow-injection iodimetric determination of captopril in pharmaceutical preparations. J. Braz. Chem. Soc., v.20, n.2, p.236-242, 2009.

SCHMIDT JR, E.; MELCHERT, W.R.; ROCHA, F.R.P. Sistema de análises em fluxo polivalente para a determinação espectrofotométrica de fármacos. Quim. Nova, v.34, n.7, p.1205-1210, 2011. 
SONG, Z.; HOU, S.; YU, X.; XIE, X.; SHAO, X. In vitro monitoring of picogram levels of captopril in human urine using flow injection chemiluminescence with immobilized reagent technique. Anal. Lett., v.39, n.6, p.1115-1127, 2006.

SUAREZ, W.T.; BONIFACIO, V.G.; MADI, A.A.; FATIBELLO FILHO, O. Flow-injection spectrophotometric determination of captopril exploiting silver chloranilate solid-phase reactor. Anal. Lett., v.42, n.7, p.973-988, 2009.

SUAREZ, W.T.; MADI, A.A.; FIGUEIREDO, L.C.S.; FATIBELLO FILHO, O. Flow-injection spectrophotometric system for captopril determination in pharmaceuticals. $J$. Braz. Chem. Soc., v.18, n.6, p.1215-1219, 2007.

SUAREZ, W.T.; PESSOA-NETO, O.D.; JANEGITZ, B.C.; VIEIRA, H.J.; FARIA, R.C.; FATIBELLO-FILHO, O. Flow injection spectrophotometric determination of $\mathrm{N}$-acetylcysteine and captopril employing Prussian blue generation reaction. Anal. Lett., v.44, n.14, p.2394-2405, 2011.

SUAREZ, W.T.; MADI, A.A.; VICENTINI, F.C.; FATIBELLOFILHO, O. Flow-injection spectrophotometric determination of $\mathrm{N}$-acetylcysteine in pharmaceutical formulations with on-line solid-phase reactor containing $\mathrm{Zn}$ (II) phosphate immobilized in a polyester resin. Anal. Lett., v.40, n.18, p.3417-3429, 2007.

TEIXEIRA, M.F.S.; MARCOLINO JR, L.H.; FATIBELLO FILHO, O. Flow injection spectrophotometric determination of adrenaline in pharmaceutical formulations using a solidphase reactor containing lead(IV) dioxide immobilized in a polyester resin. Farmaco, v.57, n.3, p.215-219, 2002.
TZANAVARAS, P.D.; THEMELIS, D.G.; ECONOMOU, A.; THEODORIDIS, G. Reversed flow-injection manifold for the spectrophotometric determination of captopril based on its inhibitory effect on the Co(II)-2,2'-dipyridyl-2pyridylhydrazone complex formation. Talanta, v.57, n.3, p.575-581, 2002.

TZANAVARAS, P.D.; THEMELIS, D.G. Review of recent applications of flow injection spectrophotometry to pharmaceutical analysis. Anal. Chim. Acta., v.588, n.1, p.1-9, 2007.

VANCEA, S.; IMRE, S.; DONÁTH-NAGY, G.; BÉLA, T.; NYULAS, M.; MUNTEAN, T.; BORKA-BALÁS, R. Determination of free captopril in human plasma by liquid chromatography with mass spectrometry detection. Talanta, v.79, n.2, p.436-441, 2009.

VOGEL, A. I. Química analítica qualitativa. São Paulo: Mestre Jou, $1981.665 \mathrm{p}$.

ZIYATDINOVA, G.K.; BUDNIKOV, G.K.; POGOREL'TSEV, V.I. Determination of captopril in pharmaceutical forms by stripping voltammetry. J. Anal. Chem., v.61, n.8, p.798-800, 2006.

Received for publication on $21^{\text {st }}$ December 2011 Accepted for publication on $10^{\text {th }}$ May 2012 
